\begin{tabular}{|c|c|c|c|c|c|c|}
\hline \multirow{4}{*}{ Impact Factor: } & ISRA (India) & $=3.117$ & SIS (USA) & $=0.912$ & ICV (Poland) & $=6.630$ \\
\hline & ISI (Dubai, UAI & $=0.829$ & РИНЦ (Russia) & $=0.156$ & PIF (India) & $=1.940$ \\
\hline & GIF (Australia) & $=0.564$ & ESJI (KZ) & $=8.716$ & IBI (India) & $=4.260$ \\
\hline & JIF & $=1.500$ & SJIF (Morocco & $=5.667$ & OAJI (USA) & $=0.350$ \\
\hline
\end{tabular}

\section{SOI: $1.1 /$ TAS $\quad$ DOI: $10.15863 /$ TAS International Scientific Journal Theoretical \& Applied Science}

\author{
p-ISSN: 2308-4944 (print) e-ISSN: 2409-0085 (online) \\ Year: 2019 Issue: $05 \quad$ Volume: 73
}

Published: $30.05 .2019 \quad$ http://T-Science.org
QR - Issue

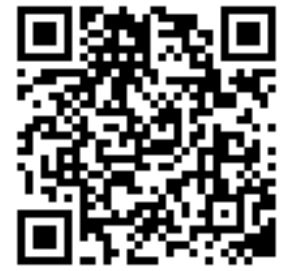

Zafar Mamaraimovich Mamatalimov

Senior researcher of the Institute of Uzbek language, literature and folklore of

the Uzbekistan Academy of Sciences, dokma@bk.ru

\title{
FOLKLORISM IN THE POETRY OF ANVAR OBIDJON
}

\author{
Abstract: In the article, the skill of using folklore is transparently exposed with examples in the poems for \\ nurseries, primaries of Uzbek public poet A.Obidjon. \\ Key words: folklorism, colorite, receipt, counting, rhythm. \\ Language: English \\ Citation: Mamatalimov, Z. M. (2019). Folklorism in the poetry of Anvar Obidjon. ISJ Theoretical \& Applied \\ Science, 05 (73), 510-515. \\ Soi: http://s-o-i.org/1.1/TAS-05-73-77 Doi: crossef https://dx.doi.org/10.15863/TAS.2019.05.73.77
}

\section{Introduction}

In spite of belonging to a particular nation the literature creators' of this nation aims stay as the same one unless the stories for children get nutrition from the traditions of folklore. As soon as the child is born he or she will start listening to the mother's lullaby, while crying they get comfort, while smiling they canreach the sense of pet. Growing gradually they tend to be friends with the tales or riddles that are according to their age. If they are brought up in perfect family, until the period of learning writing skills, they will be mainly influenced by oral speech. The youngster, who has learned to read independently, surely, enjoys as well as raises their interest when they come across well known image or event. Duringthe life they tend to live with the expressions they have acquired basing on these articles. In turn, the creators should take into consideration the artistic language, the issues relating to the public in order to get the preference to the work they want to extemporize. Folklore is one of the mainsource that provides national spirit and octoroon in the creative work.

\section{Materials and Methods}

In the opinion of G.Muminov who specifically learned the matters belonging to the traditional folklore's impact on the development of Uzbek literature; “...Folklore is not only artistic material which can be acquired to the understanding and consciousness but also rich artistic treasure that could inspire writer's imaginations motivating it, creating colorful associationsas wellas composing different complex impressions. Due to the fact that great writers achieved high creative results learning mixed types of folklore and using the best moment in their artistic work". [2, 123]

Folklore traditions play significant role in A.Obidjon's novels which are acceptable for readers. As long as his artistic work is looked through the examples, which were appeared as a result of public wisdom, grab attention like pearls in the bottom of the ocean. In particular, public epic poems are fully seen in "The fights of Meshpolvon" which have been created in prosaic poetic way. Taken as an example of epigraph, the note "Being the apprentice of wise Uzbek narrator, I started this oral epic" can be aprove of our opinion. Meshpalvan, who aimed to fight against to Sepkilshah, having no other problems except food, overcoming difficulties way by way during the travel, gaining strength in the battles becomes brave, courageous person who tends to care of people which means that it reminds the epic poems "Ravshan", "Kuntugmish". Actually, there is an image of Ravshan's son Ashikbala in the narrative. In order to describe heroes, places of events in oral epics the way saj is mainly acceptable for narrators, Ashikbala is appeared on the eyes like that "...guldor yugan ushlagan, tagida tulpor kishnagan, ko'zida qandaydir ilinj, belida bir quloch qilich, gavdasi g'o'la, bilagi quvvatga to'la bir o'spirin qarsida turibdi". Associating with Meshpalvan, Ashikbala could win the oppressors, help oppressed people to get freedom. In particular, starting the battle with the army of tax collector Nahang (!) who gathers money owing to worthless causes, he frightened them, naming the ancestors: 


\begin{tabular}{|c|c|c|c|c|c|c|}
\hline \multirow{4}{*}{ Impact Factor: } & ISRA (India) & $=3.117$ & SIS (USA) & $=0.912$ & ICV (Poland) & $=6.630$ \\
\hline & ISI (Dubai, UAF & $=0.829$ & РИНЦ (Russia & $=0.156$ & PIF (India) & $=1.940$ \\
\hline & GIF (Australia) & $=0.564$ & ESJI (KZ) & $=8.716$ & IBI (India) & $=4.260$ \\
\hline & JIF & $=1.500$ & SJIF (Morocce & $=5.667$ & OAJI (USA) & $=0.350$ \\
\hline
\end{tabular}

Kelavergin taraf bo `lsang,

Mendan gina qilma o`lsang,

Go`ro`g libek bobom bilsang,

Qilichidamu ndoq chopgan... [3, 19]

Utilizing proper characteristics of epic poems like prosaic, seven, eight, nine, eleven syllables poetic chapters is an evidence how the author learned the way of writing epic poems firmly. Because of being conveyed the views of fight above, the poet used eight syllables poetic extract, and so, this is completely suitable for the traditions of writing oral epics. Setting out the travel, the feedback of grandmother, poetic expression, devoted to the description of the market show that the oral epic "Ravshan" could serve as undoubtedly the main resource while writing "Meshpolvonning janglari". So as to make our reflections well-grounded we will give examples for 2 compositions. (The first row is taken from "Ravshan", the second row is based on "Meshpolvonning janglari")

Changib yotgan un bozori, $4+3 \quad / /$ Bordir elak bozori, $4+4$

Qo`qib yotgan jun bozori, 4+3 // Teshik chelak bozori, $\quad 4+4$

Anov mursak, to`n bozori, 4+3 // Beshik, sumak bozori, $\quad 4+4$

Pichoq bozor, qin bozori, $4+3$ // Otash kurak bozori, $\quad 4+4$

Qalpoq bozori qaysidir? 4+3 // Qanday zamon keldiki, 4+4

$$
\text { // } \quad \text { Paydo bo `lsa qiz bozor? [3, 48] 4+4 }
$$

The difference in the sequence of the turop can be elucidated with the description of the state in the epic poem. The turop $4+3$ is acceptable for the condition that Ravshan looks for Zulxumor asking people in the market whilst Ashikbala wants to get information about Aytumor questioning to passers by, the report of hump-backed old man about Kizkurgon is dependent on the order of $4+4$ turop.

Not considering the burden of poetic extracts, coming across constrained prosaic rhyme in someplaces (Мешполвон уузини хачирга жойлаб, энасининг гапини белига бойлаб, йулга тушди) the oral epic "Meshpolvonning janglari" is a perfect work. According to resoluteness and boldness Meshpolvon is worthwhile, more vivid image than Ravshan.

Writing the poems for the children, who are at the age of nursery and infant schools, demands the authors special skill. Knowing children's psychology at this age can be the key of success for the talented person. A.Obidjon created unrepeated fable poems, basing on literary recipe opportunities as well as using almost every original or rewritten genus belonging to folklore.Counting is one of the genres relating to children's game folklore which can be come across in the creative work of the author.

Bir,
Ikki,

$$
\text { O`rtada - shiringuruch. [4, 126] }
$$

Number rhythms play a significant role in this counting organized by 4 couplets. If the attention is paid, the word "shiringuruch" in the $4^{\text {th }}$ line consists of 4 syllables, due to this reason it seems not to be slightly suitable for counting rhythm. Each syllable plays peculiar importance while creating rhythm in other poetic genres which are specific for oral literature. That's to say, the burden or lack of one two syllables could impact on the smooth motion or decomposition in the counting, owing to numeration tone's essential trait for causing rhythm, syllable becomes a second tool in some places. In order to prove this viewpoint

$\begin{array}{ll}\text {-Kosasi //qa//ni? } & 3+1+1 \\ \text {-Yashirib //qo y//dim } & 3+1+1 \\ \text { theextact } & \\ \text {-Kosa //qa//ni? } & 2+1+1 \\ \text {-Sinib //qol//di... } & 2+1+1\end{array}$

let'sperform like the lines above. It can be obvious in spite of differences between syllables, countingrhythm does not change. In this way, placing numbers in separate lines in the counting above, the turop sequence $3+4$ of the last line grabs attention as a rewritten type of folklore.

Shaped diminutiveness this number counting could be the baseswhich refers to a preface in children's plays. Because the performance of preface counting is available to identify the leader (o'yinboshi) of the game or loser of the turn (qo'r).

So as to investigate the meaningful features we try to compare A.Obidjon's counting with the one of public below.

Bir, ikki, uch,

Birlashgan kuch!

$$
\text { or }
$$

Bir, ikki, uch,

Uchdanqolganpuch.

Close friendship, unity, mutual solidarity is described in the first counting whilst the abundance, sufficiency is implied in the second one as professor M.Juraev stated: "While counting something ancient person used the word "a lot" not admitting the number three like the person children also said "empty" (puch) in the play folklore not knowing the latter number". $[1,51]$

It is clear that stylized counting is enriched with a little humor. When we read it we can imagine the kids eating meal in one bowl by disputing. Objectifying the conception like militancy, not surrendering for the enemy points that the counting is renovated in terms of plot.

No number participates in the counting below. That's why it is called as word counting. As long as 


\begin{tabular}{|c|c|c|c|c|c|c|}
\hline \multirow{4}{*}{ Impact Factor: } & ISRA (India) & $=3.117$ & SIS (USA) & $=0.912$ & ICV (Poland) & $=6.630$ \\
\hline & ISI (Dubai, UAI & $=0.829$ & РИНЦ (Russia & $=0.156$ & PIF (India) & $=1.940$ \\
\hline & GIF (Australia) & $=0.564$ & ESJI (KZ) & $=8.716$ & IBI (India) & $=4.260$ \\
\hline & JIF & $=1.500$ & SJIF (Morocco & $=5.667$ & OAJI (USA) & $=0.350$ \\
\hline
\end{tabular}

the counting organized in one event similar to the meaning, likecheckmating, stopping each other by joking basing on disruptions, they help to vary the tone of counting, greatly word counting from connections.

$\begin{array}{ll}\text { - } \text { Ali,// A//li, } & 4(2+1+1) \\ \text { Ishtoning//qa//ni? } & 5(3+1+1) \\ \text { - } \text { Sot//vor//dim. } & 3(1+1+1) \\ \text { - } \text { Puli// qa//ni? } & 4(2+1+1) \\ \text { - Ayron// ol//dim. } & 4(2+1+1) \\ \text { - Ayron// qa//ni? } & 4(2+1+1) \\ \text { - } \text { Ich//vol//dim. } & 3(1+1+1) \\ \text { - Kosasi //qa//ni? } & 5(3+1+1) \\ \text { - Sin//dir//dim. } & 3(1+1+1) \\ \text { - Sinig i// qa//ni? } & 5(3+1+1) \\ \text { - Ko`mib// qo `y//dim... } & 4(2+1+1) \\ & 1(1)\end{array}$

Looking through artificially, the number of syllables in the line, the diversity of the turop sequence seems to interrupt music sequence. However, when it is expressively read as we stated, it can be evident that hand actions of readers are precisely flexible for text rhythm.

Despite being written as a style of a dialogue, this counting could be attractive by performing one person (mainly by the leader of the play) with special tone (monotone). In the counting which relates to public oral creation the ejaculations like "uch-puch", "to 'rt-o 't", "yetti-ketdi" or "Chiq", "Senchiq" "Duk!", "Gumdonbo 'l!" characteristic for which are numbers are used in the meanings of finishing to encounter together with leaving the game. In the condition of synthesis of genre, motive, rhythm the interjection "Ba-a-a!" is expressed to stop the calculation in reorganized counting.

Exaggeration is a little prosaic genre which is based on great overstatement. Firstly, the person exaggerating should notice the meanings of the words well and should be alert and wise. Moreover, listening to the opponent, mainly exaggerating even more than their opponents is a basic job. The hero of the poem "Lofchi" ("Exaggerator") Shogani is also undefeatable.

Tanib qo`ying

Sizmani.

Zo`rman, ismim

Shog`ani.

$$
\begin{aligned}
& \text { Tuyaqushni } \\
& \text { Tutganman. } \\
& \text { Patin yulmay } \\
& \text { Yutganman. [7, 80] }
\end{aligned}
$$

Children are extremely rich in dreams and tend to be complimented. There is no child who wants to surprise others by his heroic activities as well as to become famous. Swallowing the feather of the ostrich, not pulling out is strange heroism for Shogani like mentioned above. In general, the characters like, ignoring their opponents a little boastfulness, evaluating themselves a lot more than others belong to children. It is a fact that the poet united thousands of Shogani in a single image, meaning the features named above.

The examples of exaggeration are often seen in A.Obidjon's poems. In one of his poems you can read about fish that could eat whale, in another one there are actions like elephant's standing on the foot of ant not noticing, or the fly's escape wearing zebra's trousers. The hero of the poem "Tushimda" ("In my dream") is also a peer of Shagani. He is so brave that he will talk to an eight eye witch.
Sakkiz ko`zli alvasti,
Men bilan xo`p gaplashdi.
Bitta ko`zinqildilo`q,
Ikkinchisi o`ynar sho`x,
Uchinchisin suzdisal,
To 'rtinchisin qisdi sal,
Beshinchisi yiltirar,
Oltinchisi mo`ltirar,
Yettinchisi yig`lardi,
Oxirgisi uxlardi... [4, 8]

According to "Mifinarodovmira" ("International public myth") the witch is mainly described as a monster that is yellow haired, strong nailed, stone nosed and has got one eye on the eye shadow in Turkish myth. [8, 47]

In the poem above the witch has got eight eyes and each eye shows that he will be in different mood in one period. The expression proves demonologic attitudes towards ghost, demon, the evil spirit is rewritten creatively.

Although, a second poem is called "fairy tale", no public tale image is transformed. At the same period the poem itself cannot be referred as a tale. However, motive stylization relating to tale is helpful for exposing creative purpose of poet. Nowadays, being a global problem all over the world, the attitude to the nature and creatures that have equality with individuals is extremely magnificent warning in this wonderful poem. As long as humanity does not start to treat wildlife and environment in a friendly manner, the creatures like bear, fox, wolf, moved into the fairy tales from "Red Book". Undoubtedly, semicolon in the second part exposes the sadness, worry, anxiety, core of the author in the meaning. It is worthwhile telling that the word "were" stands for the events happened in the past were told by others. Sheepskin brown bear, fur hat - fox, leather suit - wolf are not really considered as mentioned by the author. On one hand, it describes the interactions which are opposite human nature. On the other hand, there is still hope for protecting our planet. Like in the fairy tales the assumption which is based on the choice of only 


\begin{tabular}{|c|c|c|c|c|c|c|}
\hline \multirow{4}{*}{ Impact Factor: } & ISRA (India) & $=3.117$ & SIS (USA) & $=0.912$ & ICV (Poland) & $=6.630$ \\
\hline & ISI (Dubai, UAI & $=0.829$ & РИНЦ (Russia & $=0.156$ & PIF (India) & $=1.940$ \\
\hline & GIF (Australia) & $=0.564$ & ESJI (KZ) & $=8.716$ & IBI (India) & $=4.260$ \\
\hline & JIF & $=1.500$ & SJIF (Morocco & $=5.667$ & OAJI (USA) & $=0.350$ \\
\hline
\end{tabular}

"claimants for premium consciousness" solving the problem, is expressed.

Qo`ng ir ayiq -

Po`stin ekan.

Bo`ri - charm

Kostyum ekan.

Tulki esa

Telpak ekan...

Bu biz uchun

Ertak ekan. [7, 88]

Belonging to A.Obidjon's poetic tales, public tales, literary tales, depending on the part "Olti arikdan olti ertak" show the effects transparently to other genres' achievements. "I used to read a lot of tales and public epic poems in my childhood. I will remember forever the images Gurugli, Alpomish, Avazkhan, Barchin, Zulkhumor, Kilichbotir" [9] said the creator. Owing to these kinds of experiences the poem "Keksaari" ("An old wasp") was written and in the poem we can come across the stylization which is peculiar for public tales. The poet efficiently used the traditional beginning in the fairy tales, as if he became wise man and he started to speak about motherland, patriotism.

Takror ertak boshlar u:

- Bor ekan-da,

Yo`q ekan.

Arilarda bir vaqtlar

Bo ’gan ekan keng Vatan...

Doim shuni aytardi

Nabiralar yonida.

Eski ertak

Hech kimning

Tegmas edi joniga. [7, 40]

Although it was not told the reasons why wasps deprived of their land along with used holes - fins as their habitat, reader feels some displeasures. Whatever happens, presumably, wasps gave their extensive land to the enemy, because of unfriendly terms, betrayal, maybe for other reasons. As a consequence, an old wasp tries to rebuild glorious past by raising the senseof patriotism, peacefulness, militancy in the mood of grandchildren. Differing from the previous poem, creator organized the image of the poem "Old Wasp" basing on the trope like in fantastic tales. It cannot be surprising that the most interesting and favorite genre for kids is riddle.

The reason is that that they tend to do the tasks once independently not wanting to observe the movements are acted by adults. In comparison with chill performing the riddles, other folklore genres, the kids become participants to the process of events not being observer or listener by the way. Undoubtedly, it gives them fun. The poem "Kim tuzatadi?" ("Who corrects?") plased in the collection "Jajji-jajji kulchalar" ("Rather small, small hands") is relatively for 2-5 year old children. Young readers are inspired to find the creature by intentionally changing the sounds of animals and birds into the other ones. According to a great German linguist German Paul, imitational words like "tu-tu" (hen's voice), "mu-mu" (cow's voice), "vov-vov" (dog's voice) play an important role in children's poetic speech. If people focus on the saying, the poetic function of the poem written as a riddle is sure to be known.

Quyonim bor- "vov-vov" der,

Kuchugim bor - bedayer.

Xo`rozim suvda suzar,

Mushugim arqon uzar.

Tongda qichqirib: "quq-qu-u",

Balig `im bermas uyqu... [7, 89]

The poem "Sabzi" ("Carrot") is a product of creative approach. Starting to read the poem, we can get information about the hero invigorating by means of intoxicants grows in the field and has a slender skin. However, these attributes cannot illustrate the portrait, exact appearance of narrator. Until the line "I am a gold skin" it is difficult to know the owner of speech. The speech real addressee - depending on the carrot can be explained to the fans of the poem (Yer tagida oltin qoziq) by the poet using Uzbek riddles effectively.

\section{Yupqagina}

Po`stim bor.

Dalada

Ko`p do`stim bor.

Topishmoqda

Yoziqman,

O`sha

"Oltin qoziq"man. [7, 9]

Basing on maths puzzles, $\mathrm{ABC}$ riddles, collections are composed in the creative work of the poets like P.Mumun, T.Adashbaev, D.Rajab, A.Akbar. Apart from a few riddles, A.Obidjon could not beknown as an efficient writer in this genre.

The creative work of poet is rich in real, rebuilt, simple folklore. Whichever poetic part is analyzed, it can be seen that the poet uses proverbs, sayings, expressions skillfully in order to expose his artistic aim. If we take the poem "Botirvoyning kundaligi" as an example, the expression "Chicken is counted in autumn" - "11 aprel", the expression "East or west - home is best" - " $7^{\text {th }}$ July" are provided with life giving features.

Public proverb could be atitle in the poem "Shudgorda quyruq yotganmish" ("There is a tail in the arable land").

Sichqonaytdi

Ilonga.

Ilonaytdi

Quyonga. 


\begin{tabular}{|c|c|c|c|c|c|c|}
\hline \multirow{4}{*}{ Impact Factor: } & ISRA (India) & $=3.117$ & SIS (USA) & $=0.912$ & ICV (Poland) & $=6.630$ \\
\hline & ISI (Dubai, UAE & $=0.829$ & РИНЦ (Russia & $=0.156$ & PIF (India) & $=1.940$ \\
\hline & GIF (Australia) & $=0.564$ & ESJI (KZ) & $=8.716$ & IBI (India) & $=4.260$ \\
\hline & JIF & $=1.500$ & SJIF (Morocce & $=5.667$ & OAJI (USA) & $=0.350$ \\
\hline
\end{tabular}

Quyon aytdi

Qoplonga.

Qoplon... tushdi-

Qopqonga!

Mouse, snake, leopard, rabbit are humans as we are in fact. There may be some people who want free intake not working at all. Nobody guarantees that the people, who cannot see reality having desire not to work might be in the condition of leopard the theme is also extremely important for today. Despite having facilities, new conveniences day by day in Uzbekistan, there are still compatriots, who wish a lot more welfare, treasure going to foreign countries, becoming slave, dying in torture. Their destiny is described in this poem.

On purpose, the poet doesn't say one part of the proverb "If there is not a trouble..." So, the indication is a sage for wise, clever people.

Kecha oldim, jiyancham,

Yig lab yozgan xatingni.

Aytmasang ham bo `lardi

Oldi-qochdi dardingni.

Mendan ahvol so`rabsan,

Yozsam ekan nima deb?

Xullas, ishlab yuribman

O`z etimni o`zim yeb. [7, 198]

Meaning the saying, the more pencil is used the less it becomes, the expression "Eating self meat" gives poetic attraction to pencil's speech. If this expression is used for pen, probably there may not be such productiveness. Remembering the usage of penal earlier than a pen in the society, also the appeal "my little cousin" the advice for pen is worthwhile. The expression "Making a fig by beating the first time" shows the meanings "punish", "telling off wittily" among people. When these expressions are used for communication among children, we can be a witness of completely different view belonging to child;

"Bittauribanjirqilaman", -

Deya Ilhomxo`m raygankezda,

Esga tushib Norning anjiri

Unikiga yo`l oldim tezda. $[7,143]$

A.Obidjon has got a number of poems which are particular for fable genre written in creative traditional ways. Including, poem, the biography of camel expressed the pitiful condition of person not having their independence, is a result that has artistic nutrition in Gulxaniy's "Zarbulmasal" in the extract "Tuyabilanbo taloq" ("Camel and her child") like a fable "Chumoli va Qurbaqa" ("An ant and afrog") in the poem "Eski tom" ("An old roof"), it is concluded proportion from narration saying "get ready for the winter in summer". The author's aim is exposed like a conversation talk in "Tuya bilan bo 'taloq" ("Camel and her child") whereas the speech of hero becomes a tool describing internal, "I" emanating from the demand of biography in the poem "Tuyaning tarjimayi holi" ("The biography of camel")

Dosh beraman ochlikka

Suvsizlikka chidayman.

Dam berishsa, cho kkalab

Burganlarni hidlayman. [7, 182]

The frog in "Chumoli va Qurbaqa" "“An ant and a frog") spent whole summer enjoying, having fun. In winter, he went to the ant pitifully in order to borrow. Promising to pay twice more next summer, the frog did not know spending this season with fun too. Again the frog is forced to ask favour from the ant not putting up with cold in winter. In the poem "Eski tom" the magpie has the same destiny as the frog.

No repairing the house in time owing to the rainfall through the roof during precipitation, it has to ask the help from stock.

Whereas the frog used the phrase "uyingga bug 'doy to "lgur" in order to make the ant feel sorry, the magpie complained about his condition much in the fable (Joy bering men polaponga). The fable ended with ant's ignorance to frog's complaint second time. The poem "Eski tom" completed by the help of stock to the magpie placing it in its own house and the advice.

In "O'zbek tilining izohli lug'ati” ("Uzbek explanatory vocabulary") the word "marsiya" is explained like writing one poem for the memory of person who died. $[8,547]$ We can come across such kind of poems which are devoted to the children died early or grandparents, parents, relatives in the literature.

In the poem "Botirvoy yozgan marsiya", Botirvoy wrote marsiya for being deprived of hot and soft wool sock sorrowing.

Jun paypog `im bor edi

Issiq va yumshoq.

Tutingandik o'tgan qish

Ikkimiz o`rtoq.

Mana yana qish keldi,

Men-ku sog`-omon.

"O`rtog 'im"ni, he afsus,

Yeb ketdi sichqon. [5, 19]

If the poem is read without a title, the aim will be the information about, Somebody's sock has been eaten by mouse. In this way, the title services to increase the humor one more time in the poem. Submitting the genre mourning to express comical situations shows the creator's making jokes from all sides.

Among the examples of ceremony folklore Kelinsalom plays an essential role. To introduce the bride to the members of a new family, to wish her best, to give feedback include a main point. "Salomnomalar" relating to the group "Bulbulning cho "pchaklari" have been exposed basing on the 


\begin{tabular}{|c|c|c|c|c|c|c|}
\hline \multirow{4}{*}{ Impact Factor: } & ISRA (India) & $=3.117$ & SIS (USA) & $=0.912$ & ICV (Poland) & $=6.630$ \\
\hline & ISI (Dubai, UAE & $=0.829$ & РИНЦ (Russia & $=0.156$ & PIF (India) & $=1.940$ \\
\hline & GIF (Australia) & $=0.564$ & ESJI (KZ) & $=8.716$ & IBI (India) & $=4.260$ \\
\hline & JIF & $=1.500$ & SJIF (Morocce & $=5.667$ & OAJI (USA) & $=0.350$ \\
\hline
\end{tabular}

melody of kelinsalom. Kelinsalom is often created in the style of ikkilik (two lines) or turtlik (four lines). Rhyming is mainly formed a-a, b-b, d-d; a-a-a-b, d-dd-b, e-e-e-b...

Salomnomalar were written as a style of gazal. The order of rhyme is suitable for simple gazal. salom,

Qo`rqoqlarning qo`rqog`i g`ilay Quyonga salom.

Yo`qdir yaqin o`rtog`i, sho`rlik Chayonga

Shoxdan shoxga yugurgan, dumida uy supurgan, salom.

Yong`oq chaqib tupurgan, sho`x Olmaxonga

Arg`amchidek buralar, yantoqlarga o`ralar, $[6,11]$

Qo`ng iz o`t samo`ralar, bo`g`ma Ilonga salom...

If we form the poem which is written in the style of musajja gazal having internal rhyme apart from external one like turtlik (four lines) a-a-a-d, b-b-b-d... rhymes can be available for the melody kelinsalom according to the sequence of the turop $4+3$. While performing kelinsalom the performer could praise somebody to the skies or else someone can be criticized gently by telling unworthy defects. While the squirrels neatness is commended, in turn rabbit, scorpion snakes are negatively described in "Salomnomalar".

Being short story based on laugh, anecdote is delightful for both children and adults. Mainly, Kal, Kusa, Aldarkusa, Afandi is visible in the image of naive, gullible, sly or wise, punctual, nimble in it. In the poem "Kuvnokchol" Nasriddin Afandi meets the boy named Nor who carries grass on his back.

Initially, greeting with him, he called him "sher bola". Then he asks a little hayfor the donkey. Being fond of praise Nor gives him hay. As soon as the donkey has eaten the hay, the old man thanks to the boy. While asking the time to pay back:

"Xo`sh, men ajriq yedimmi?-

Dedi-yuchol, g`o`laydi.

O`tni yedi eshagim,

Qarzni o`zi to`laydi’. [5, 24]

When the boy gets the answer like above Nor is not angry knowing the person he met, he smiles.

\section{Conclusion}

The person, who is taken in, notices the real state after a while in public anecdotes. Owing to Nasriddin Afandi a lied man realized the fact later. (After the events finishes with the victory of kindness). Moving this motive to the poem, the old man is not exposed until the end of the event. After Nor's exclamation, the reader starts smile.

Seeing this or that population's colourful, different oral work, we could comprehend that those people's culture is deep and high. It is worthwhile being proud that, the Uzbek are the richest one over the world in this way. [9] Really, A.Obidjon created valuable artistic, specific compositions in children's literature learning public's rich spiritual heritage creatively.

\section{References:}

1. Jo`rayev, M. (1991). Sehrli raqamlar siri. Toshkent: O`zbekiston.

2. Mo`minov, G`. (1986). O`zbek sovet adabiyoti taraqqiyotida folklorning roli. Toshkent: Fan.

3. Obidjon, A. (1994). Meshpolvonning janglari. Toshkent: Cho`lpon.

4. Obidjon, A. (2006). O`g irlangan pahlavon. Toshkent: Cho'lpon.

5. Obidjon, A. (2013). Jajji-jajji kulchalar. Toshkent: O`qituvchi.

6. Obidjon, A. (1986). Masxaraboz bola. Toshkent: Yosh gvardiya.
7. Obidjon, A. (1987). Juda qiziq voqea. Toshkent: Yulduzcha.

8. Tokarev, S. (1980). Mifi narodov mira. Moskva: Sovetskaya ensiklopediya.

9. (n.d.). Retrieved 2019, from http://khdavron.uz/yangiliklar/muborak-kin/anvarobidjon-aytmishlari-va-hikmatlari.html

10. (2006). O`zbek tilining izohli lug `ati. 5 jildli. 2jild. Toshkent: O`zbekiston milliy ensiklopediyasi Davlat ilmiy jamiyati. 